\title{
Identification of Microplastic Composition on Clams (Gafrarium tumidum) and Sediments in Pari Island, Seribu Islands, Jakarta
}

\author{
Winesti Tubagus*, Sunarto, Mochamad Rudyansyah Ismail, Lintang Permata Sari Yuliadi \\ Departement of Marine Sciences, Faculty of Fisheries and Marine Sciences, Padjadjaran University \\ Jl. Raya Bandung Sumedang KM 21, Jatinangor, West Java 45363 Indonesia \\ Email: winestitubagus@gmail.com
}

\begin{abstract}
Microplastic is one of the pollutants that can contaminate marine biota even spread in sea waters and coastal substrate because of the sizes ranges to $10 \mu \mathrm{m}^{-2} . \mathrm{mm}$. This pollutant is spread in marine waters and found at Pari Island, of Seribu Islands, Jakarta. This research aims to identify the amount of abundance, type, size, and color of microplastic that was found in sediment and shell samples. The research method used was a survey method and laboratory analysis. The method consists of three parts, namely field data collection, identification using a microscope, and describing the results of identification. All sediment and shell samples were identified as being contaminated with microplastics. Microplastic are found in fiber, fragment, and film type. That color found including black, yellow, red, blue, green, chocolate, and clear. The most dominant microplastic color is black and the most dominant microplastic size is the small size group. The highest microplastic abundance in sediment samples from 3 stations is found in samples taken by Station 2 with an average of 43.67 particles.100 g-1 of dry sediment and the most dominant type is the fiber type from all sediment samples. The most dominant type of mussels sample is fragment type and the average abundance of microplastics in the highest sample of mussels is worth 17.33 particles. ind ${ }^{-1}$.
\end{abstract}

Keywords: Clams, microplastic, Pari Island, polution, sediment

\section{Introduction}

Plastics that have ended in seawater over time will experience a reduction in size to micro $(5 \mathrm{~mm})$ caused by several factors including the activity of UV light and abrasion through wave action so that it can accumulate in high amounts in seawater and sediments (Hidalgo et al., 2012). Microplastic size is very small and a large amount in the ocean makes it ubiquitous and bioavailability for high aquatic organisms. As a result, microplastics can be consumed by marine biota (Li et al., 2016).

Pari Island, Thousand Islands is one of the selected tourist destinations in Jakarta. The increase in the number of visitors is directly proportional to the problem of rubbish on the small island, both the shipment trash or garbage originating from tourists or visitors. Gafrarium tumidum is a type of biota from the shellfish group, bivalve class. This type of clam can be found in the waters around the Pari Island group. This clam has often been used for consumption locally by residents of Pari Island.

Microplastic pollution has pervaded relatively pristine environments (Cordova et al., 2016). According to GESAMP (2010), shellfish habitat is included in the group of marine biota whose movements are slow, their life settles in a certain habitat that is in sediments or the seabed so that bioaccumulation and bioconcentration take place more intensively, Shellfish take food by filtering water (filter feeder) so that it is easy experiencing accumulation of pollution, which causes scallop as one of the excellent indicators in monitoring environmental pollution. This research aims to identify microplastics that exist in sediments and Gafrarium tumidum on Pari Island based on type, size, and color.

\section{Material and Methods}

Samples were taken at 3 stations on Pari Island (Figure 1). Station 1 is near Perawan Beach, which is a tourist destination on Pari Island. Station 2, located on Reggae Beach, is a new tourist location and not many tourists know about it. Before becoming a tourist attraction, this location contained a lot of trash scattered along the beach. Station 3 is near the mangrove forest. Sampling of sediments and shellfish is done in-situ using a shovel on the surface of coastal sediments. All collected samples are wrapped using plastic ziplock and stored in a cool box.

Clams samples that have been collected were measured in length and weight. Clams samples were removed from their shells and then mashed with a 


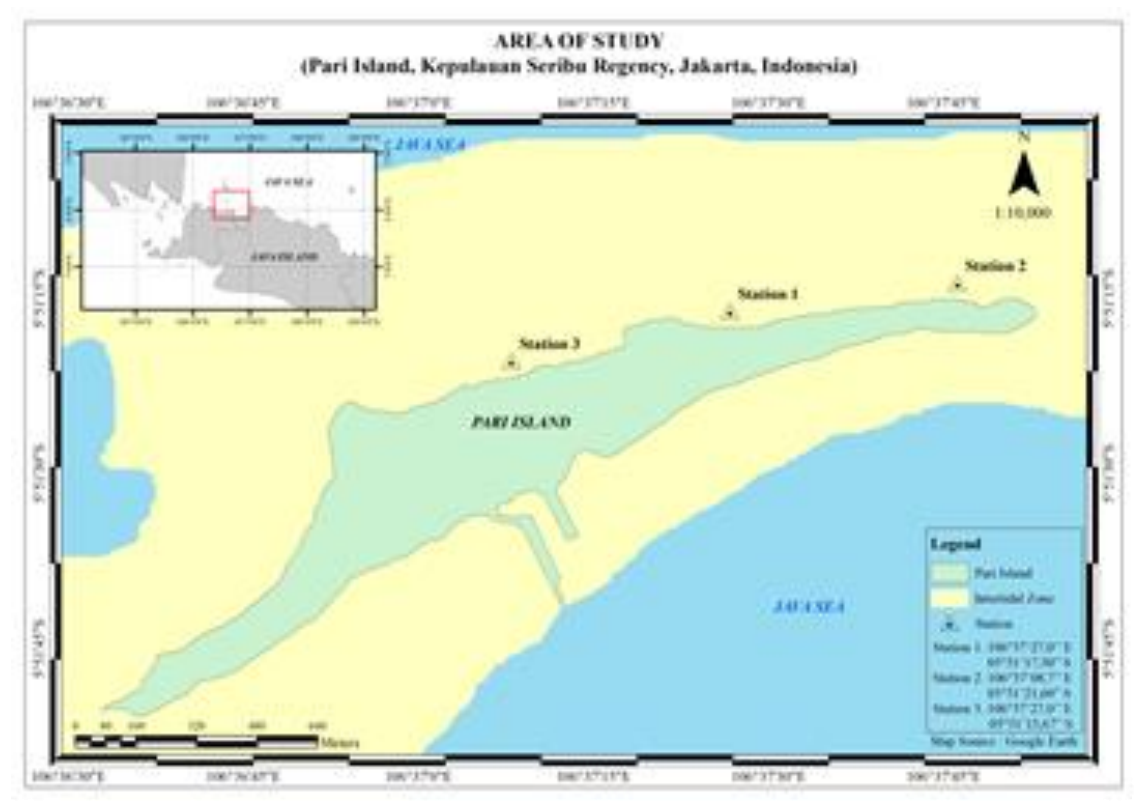

Figure 1. Pari Island, Jakarta

mortar and then structured (Li et al., 2015; Jabben et al., 2017). The digestion process was carried out using a $10 \% \mathrm{KOH}$ solution then incubated at $60^{\circ} \mathrm{C}$ for $24 \mathrm{~h}$ and added $30 \% \mathrm{H}_{2} \mathrm{O}_{2}$ solustion (Rochman et al., 2015). After being destructed, the sample is then isolated and filtered.

Sediment samples were covered, dried in the sun and weighed. Sediment sifting and granulometry analysis were carried out to determine the type of sediment at each station. Before the microplastic separation stage is carried out, the pre-treatment stage is carried out on the sample. Sediment added $10 \% \mathrm{H}_{2} \mathrm{O}_{2}$ (Frias et al., 2018), stirred using a glass rod or iron spoon, covered using aluminum foil, soaked for 18-24 h. Shellfish and sediment samples were isolated using saturated $\mathrm{NaCl}$ solution (Claessens et al., 2013). Isolated sample solution, then filtered. Filtration results were observed using a microscope. Microplastics were identified using a microscope by type (Dewi et al., 2015), size (Storck et al., 2015), and color.

\section{Results and Discussion}

\section{Sediment type}

The results of granulometric analysis of sediment samples showed that all stations have the same type of sediment. Based on the results of granulometry analysis showed that the type of sediment in the three stations was sand gravel with slight pebbles. Each station consists of three factions, namely, gravel, sand, and silt. Stations 1, 2, and 3 are dominated by silt with values of $68.4 \%, 65.7 \%$, and
73.9\% for each station (Table 1). Sediments are useful record of past and present plastic leakage from the waste stream into the marine environment (Willis et al., 2017). Microplastic density is directly proportional to the content of clay and dust (Wahyuningsih et al., 2018). In general, sediments that have a fine texture are most likely to facilitate the accumulation of microplastic processes in sediments. (Noor, 2012).

\section{Clams size}

At each station, nine samples were taken. Station 2 is dominated by heavier samples than Station 1 and 3 (Table 2.). The average weight of the contents of the shellfish samples taken from Station 1 and 3 is equal to $1.47 \mathrm{~g}$.

\section{Microplastic abundance in sediments and clams}

The table above shows the comparison of the number of microplastics from three stations where the most microplastics are obtained at Station 2, namely sediment from Reggae Beach with an average amount of 43.67 particles.100g-1 (Table 9), this is assumed to be the location of Station 2, namely Reggae Beach, frequent buildup of congenital rubbish on this beach. The second highest microplastic abundance was at Station 1, with an average value of 35.67 particles.100g-1. A fairly high number of microplastics is possible because Station 1 is on Pantai Pasir Perawan, which is the main tourist beach on Pari Island. The number of microplastics in a location depends on the activity and population density at that location (Browne et al., 2010). The lowest abundance of microplastic is found in station 
3 , which is 28 particles. $100 \mathrm{~g}^{-1}$, this can be caused by the location of Station 3 near the mangrove forest (Table 3.). Mac Farlane and Burchett, 2001, stated that the ecological balance of the coastal waters environment will be maintained if the presence of mangroves is maintained because mangroves can function as a biofilter, binding agents and pollution traps.

Table 3 shows that the highest total number of microplastics is found in sample station 2 with the number of 156 particles with an average abundance of microplastic 17.33 particles.ind ${ }^{-1}$. This data is directly proportional to the average sediment abundance data found at Station 2. This is also suspected because the average weight of samples at Station 2 has the highest value of $2.08 \mathrm{~g}$. The number of microplastic particles in the shells is higher than that of the sediment, however, the size of the microplastics found in the sample of the shells is smaller.

\section{Microplastic type}

Based on the results of the study found that the type of microplastic contained in sediments at three stations is dominated by microplastic types of fiber and fragments. Film-type microplastics are also found, although not as many as fiber and fragment types.

The high value of fragment particles found in both sediment samples and shell samples can be influenced by oceanographic factors such as coastal currents, tides, and fishing activities carried out by fishermen, in the presence of these factors fragments which are pieces of plastic products with very strong polymer synthesis trapped in sediment. Another factor is the location of sampling close to the coast of the island, the amount of community garbage such as detergent wrapping bottles, food wrapping plastics, ships, fishing rods are the triggers for microplastic deposition in sediments.

Table 1. Sediment types

\begin{tabular}{ccccl}
\hline Station & $\begin{array}{c}\text { Gravel } \\
(\%)\end{array}$ & $\begin{array}{c}\text { Sand } \\
(\%)\end{array}$ & $\begin{array}{c}\text { Silt } \\
(\%)\end{array}$ & Information \\
\hline 1 & 0,1 & 31,5 & 68,4 & Sand Gravel with Slight Pebbles \\
2 & 0,3 & 34,0 & 65,7 & Sand Gravel with Slight Pebbles \\
3 & 1,1 & 25,0 & 73,9 & Sand Gravel with Slight Pebbles \\
\hline
\end{tabular}

Table 2. Average lengths and weights of clams

\begin{tabular}{cccc}
\hline Station & Average lengths $(\mathrm{cm})$ & Average weights $(\mathrm{g})$ & Average content weights $(\mathrm{g})$ \\
\hline 1 & 3,53 & 13,44 & 1,47 \\
2 & 4,63 & 22 & 2,08 \\
3 & 3,78 & 15,11 & 1,47 \\
\hline
\end{tabular}

Table 3. Abundance of microplastic

\begin{tabular}{ccccccc}
\hline \multirow{2}{*}{ Total } & \multicolumn{2}{c}{ Station 1 } & \multicolumn{2}{c}{ Station 2 } & \multicolumn{2}{c}{ Station 3 } \\
\cline { 2 - 7 } & $\begin{array}{c}\text { Sediment } \\
\text { (particles.100g-1) }\end{array}$ & $\begin{array}{c}\text { Clam } \\
\left.\text { (particles.ind }{ }^{-1} \text {. }\right)\end{array}$ & $\begin{array}{c}\text { Sediment } \\
\left(\text { particles.100g-1) }^{-1}\right.\end{array}$ & $\begin{array}{c}\text { Clam } \\
\left(\text { particles.ind }^{-1} \text {.) }\right.\end{array}$ & $\begin{array}{c}\text { Sediment } \\
(\text { particles.100g-1) }\end{array}$ & $\begin{array}{c}\text { Clam } \\
\left(\text { particles.ind }^{-1} \text {.) }\right.\end{array}$ \\
\hline $\begin{array}{c}\text { Abunda } \\
\text { nce }\end{array}$ & 35,67 & 14,56 & 43,67 & 17,33 & 28 & 13,44 \\
\hline
\end{tabular}

Table 4. Total microplastic based on types

\begin{tabular}{ccccccc}
\hline \multirow{2}{*}{ Type } & \multicolumn{2}{c}{ Station 1 } & \multicolumn{2}{c}{ Station 2 } & \multicolumn{2}{c}{ Station 3 } \\
\cline { 2 - 7 } & Sediment & Clam & Sediment & Clam & Sediment & Clam \\
\hline Fiber & 51 & 35 & 101 & 40 & 28 & 60 \\
Fragment & 79 & 96 & 28 & 116 & 53 & 61 \\
Film & 0 & 0 & 2 & 0 & 3 & 0 \\
\hline
\end{tabular}


Fiber-type microplastics are elongated plastic fibers and are derived from monofilament fragmentation in fishing nets, ropes, and synthetic fabrics. Fiber can come from high fishing activities around the area so that it contributes debris into seawater (Katsanevakis and Katsarou, 2004; Hazimah and Obbard, 2013). The number of microplastic types of fiber that are found to be likely originated from boat ropes that are not used by fishermen or who experience friction and then break down into very small plastic particles which are then carried by the incoming flow into the waters. Film-type microplastics were only found in sediment samples with a total of 4 particles from all stations (Table 4.). Film-type microplastics are not found at all in shell samples. According to Kingfisher (2011), film is a secondary plastic polymer derived from fragmentation of plastic bags or plastic packaging and has a low density. The film has a lower density than other microplastic types so it is more easily transported to the highest tides.

\section{Microplastic size}

Microplastic itself is divided into 2 size categories, namely large microplastics $(1-5 \mathrm{~mm})$ and small microplastics $(<1 \mathrm{~mm})$ (Storck et al., 2015). Microplastic size can be very different because plastics have a variety of different types, and also because physical and chemical factors are very influential in the destruction of microplastics causing microplastics to have different sizes (Hastuti et al., 2014).

Table 5 shows that small size microplastics predominate in both sediment samples and shell samples, one of the factors is that large microplastic sizes are easily carried back by tides and currents, thus reducing the possibility for large microplastics to settle in sediments. The highest large microplastic samples were found in shellfish samples from Station 2 (Table 5.). The sample size of shells at Station 2 which tends to be larger than the sample shells of Station 1 and 3 can be one of the factors.

\section{Microplastic color}

The dominant microplastic color is black (Table 6). In addition to black, blue is also quite common, according to Hastuti (2014), saying black microplastic is the result of fragmentation from plastic bags macro waste. Black can indicate the amount of contaminants absorbed in microplastics and other organic particles. Black microplastic also has the ability to absorb high pollutants, also affects the texture of microplastics (Hiwari et al., 2018). Blue microplastics generally come from boat ropes or fishing nets, while yellow and green microplastics come from clothes that are washed and then the thread enters the waters. Clear microplastics can also originate from microplastics that have undergone photochemical processes that cause loss of color pigments in these microplastics.

\section{Conclusion}

The highest number of microplastics in the sediment samples was found in sample Station 2, with a value of 43.67 particles.100.g-1. The highest average number of microplastics in shellfish samples is at Station 2, with a value of 17.33 particles.ind ${ }^{-1}$.

Table 5. Total microplastic based on group-size

\begin{tabular}{ccccccc}
\hline \multirow{2}{*}{ Group-size } & \multicolumn{2}{c}{ Station 1 } & \multicolumn{2}{c}{ Station 2 } & \multicolumn{2}{c}{ Station 3 } \\
\cline { 2 - 7 } & Sediment & Clam & Sediment & Clam & Sediment & Clam \\
\hline Big & 37 & 23 & 54 & 33 & 16 & 8 \\
Small & 70 & 108 & 77 & 123 & 68 & 113 \\
\hline
\end{tabular}

Table 6. Total microplastic based on color

\begin{tabular}{ccccccc}
\hline \multirow{2}{*}{ Color } & \multicolumn{2}{c}{ Station 1 } & \multicolumn{2}{c}{ Station 2 } & \multicolumn{2}{c}{ Station 3 } \\
\cline { 2 - 6 } & Sediment & Clam & Sediment & Clam & Sediment & Clam \\
\hline Black & 76 & 128 & 55 & 152 & 59 & 121 \\
Yellow & 0 & 1 & 10 & 3 & 0 & 0 \\
Red & 5 & 2 & 14 & 4 & 4 & 0 \\
Blue & 19 & 0 & 2 & 0 & 0 & 0 \\
Green & 6 & 0 & 0 & 0 & 0 & 0 \\
Clear & 1 & 0 & 2 & 0 & 2 & 0 \\
Chocolate & 0 & 0 & & & 13 & 0 \\
\hline
\end{tabular}


The most dominant microplastic color is black and the most dominant microplastic size is the small size group. The most dominant type of microplastic in the sediment sample is the type of fiber, while the type of microplastic that dominates in the sample of the shell is the type of fragment.

\section{References}

Browne, T. \& Kershaw, P.J. 2010. Microplastic particles as a vector in persistent transport, bioaccumulating and toxic substances in the ocean. Proceedings of the GESAMP International Workshop on Microplastic Particles as a Vector in Transporting Persistent, Bio-Accumulating and Toxic Sub-Stances in the Ocean. GESAMP Rep. Study. No. 82, 68pp.

Claessens, M., Van Cauwenberghe, L., Vandegehuchte, M.B. \& Janssen, C.R., 2013. New techniques for the detection of microplastics in sediments and field collected organisms. Mar. Poll. Bull., 70(1-2): 227-233. doi: 1016/j.marpolbul.2013.03.009

Cordova, M.R. \& Wahyudi, A., 2016. Microplastic in the deep-sea sediment of southwestern Sumatran Waters. Mar. Res. Indo., 41(1): 27-35. doi: $10.14203 /$ mri.v41i1.99

Dewi, I.S., Budiarsa, A. \& Ritonga, I. 2015. Microplastic Distribution of sediments in Muara Badak, Kutai Kartanegara Regency. Depik, 4(3): 121-131. doi: 10.13170/depik.4.3.2888

Frias, J., Pagter, E., Nash, R., O'Connor, I., Carretero, O., Filgueiras, A., Viñas, L., Gago, J., Antunes, J., Bessa, F. \& Sobral, P., 2018. Standardised protocol for monitoring microplastics in sediments. Deliverable 4.2.

GESAMP (IMO / FAO / UNESCO-IOC / UNIDO / WMO / IAEA / UN / UNEP. 2010. Joint Group of Experts on the Scientific Aspects of Marine Environmental Protection),

Hastuti, A.R., Yulianda, F. \& Wardiatno, Y., 2014. Spatial distribution of marine debris in mangrove ecosystem of pantai indah kapuk, Jakarta. Bonorowo Wetlands, 4(2):94-107. doi : 10.13057/bonorowo/w040203

Nor, N.H.M. \& Obbard, J.P., 2014. Microplastics in Singapore's coastal mangrove ecosystems. Mar. Poll Bull., 79(1-2): 278-283. doi: 10.1016/j. marpolbul.2013.11.025.
Hidalgo-Ruz, V., Gutow, L., Thompson, R.C. \& Thiel, M., 2012. Microplastics in the marine environment: a review of the methods used for identification and quantification. Environ. Sci. Technol., 46: 3060-3075. doi: 10.1021/es2031505

Hiwari, H., Purba, N.P., Insan, Y.N., Yuliadi, L.P. \& Mulyani, P.G. 2018. Microplastic Waste Conditions on Sea Levels Around Kupang and Rote, East Nusa Tenggara Province. Pros SemiPrivate Vocational School of Biodiv. Indon., 5(2): 165-171.

Katsanevakis, S. \& Katsarou, A. 2004. Influences on the distribution of marine debris on the seafloor of shallow coastal areas in Greece (Eastern Mediterranean). Water, Air, Soil Poll., 159: 325337. doi: 10.1023/B:WATE.0000049183.17 150.df

Kingfisher, J. 2011. Micro-plastic debris accumulation on puget sound beaches. Port Townsend Marine Science Center.

Li, J., Qu, X., Su, L., Zhang, W., Yang, D., Kolandhasamy, P., Li, D. \& Shi, H., 2016. Microplastics in mussels along the coastal waters of China. Environ. Poll., 214: 177-184. doi: 10.1016/j.envpol.2016.04.012

Mac Farlane, G.R. \& Burchett, M.D. 2001. Photosynthetic Pigments and Peroxidase Activity as Indicators of Heavy Metals Stress in the Gray Mangrove Aviccenia marina (Forsk.) Vierh. Mar. Poll. Bull., 42: 233-240. doi: 10.1016/S0025326X(00)00147-8

Noor, D. 2012. Introduction to Geology. Bogor: Pakuan University Press.

Storck, F.R., Kools, S.A. \& Rinck-Pfeiffer, S., 2015. Microplastics in fresh water resources. Global Water Research Coalition, Stirling, South Australia, Australia. 7 pages

Rochman, C.M., Tahir, A., Williams, S.L., Baxa, D.V., Lam, R., Miller, J.T., Teh, F.C., Werorilangi, S. \& Teh, S.J., 2015. Anthropogenic debris in seafood: Plastic debris and fibers from textiles in fish and bivalves sold for human consumption. Scientific Reports, 5:14340. doi: 10.1038/srep 14340

Wahyuningsih, H., Bangun A.P. \& Muhtadi, A., 2018., The relation of sediment texture to macro- and microplastic abundance in intertidal zone. IOP 
ILMU KELAUTAN: Indonesian Journal of Marine Sciences September 2020 Vol 25(3):115-120

Conf. Ser.: Earth Environ. Sci. 122:012101 doi: 10.1088/1755-1315/122/1/012101

Willis, K.A., Eriksen, R, Wilcox, C. \& Hardesty, B.D., 2017. Microplastic Distribution at Different
Sediment Depths in an Urban Estuary. Frontiers Mar. Sci. 4: 419. doi: 10.3389/fmars. 2017. 00419 